\title{
U.S. MUSLIM
}

\section{Philanthropy AfTER 9/11}

\author{
Kambiz GhaneaBassiri \\ Reed College
}

Since 9/11, U.S. Muslim philanthropy has generally been framed in terms of national security and civil liberties. In practice, however, U.S. Muslims' charitable giving has posed no threat to national security, nor has the government's closing of some of the largest Muslim relief organizations after 9/11 had the chilling effect that many predicted it would have on U.S. Muslims' giving. This article argues that American Muslim philanthropy post-9/11 belies enduring presuppositions about the alleged "rigidity" of Islamic norms and the alleged "insularity" of the U.S. Muslim community. Each of these presuppositions has yielded widespread misapprehensions about the nature of Muslim philanthropy in the U.S. since 9/11. Contrary to these misapprehensions, the actual philanthropic practice of the U.S. Muslim community in the post-9/11 moment highlights the polyvalence and fluidity of the public practice of Islam. In the fluid space of practice, American Muslims have brought together Islamic vocabularies of charity and American legal and sociopolitical norms regarding philanthropy to forge new relations across groups of varying social, religious, political, cultural, and economic backgrounds.

Keywords: American Islam, Muslim charities, zakat, "war on terror," anti-Muslim sentiments, Holy Land Foundation, Benevolence International Foundation, Global Relief Foundation, KindHearts

Until recently, the study of Islam in the United States focused primarily on questions of assimilation and identity formation, with the aim of ascertaining how well Muslims fit into U.S. society. These questions were propelled by a general assumption that U.S. society and Islamic beliefs and practices are incongruent and thus require a special act of reconciliation worthy of scholarly attention. ${ }^{1}$ More recent research into the centuries-old presence of Muslims in the United States, however, has shown that this assumption is not historically tenable (Curtis, 2013). Scholars have thus begun to explore Islam as one of a number of religions practiced in America since colonial times. In doing so, they are complicating facile dichotomies between Islam and the West, modernity and tradition, and immigrant and indigenous Muslims. Rather than approaching the study of Muslims in the United States with such preconceived binaries, more recent scholarship

Copyright (C) 2017 Kambiz GhaneaBassiri

http://scholarworks.iu.edu/iupjournals/index.php/jmp

DOI: https://doi.org/10.18060/21415

1 I have discussed these issues in some depth; see GhaneaBassiri (2010, 4f). 
on American Islam focuses on the lived experiences of Muslims. It explores how U.S. Muslims have built communities, institutions, and intellectual networks based on their beliefs and traditions and in relation to relevant legal, social, and political structures as well as the plurality of religions, cultures, races, and ethnicities in the United States. In light of this shift, the study of Muslim philanthropy in the United States is not only welcome but also well overdue as to how it focuses scholarship on how U.S. Muslims bring their religious values, their sense of individual and communal needs, and American social norms and political values into dialectical relations that cross social, political, and economic boundaries through giving.

\section{Distinctive Contextual Practices of Zakat in the United States}

Given that zakat, one of the pillars of Islam, enshrines charity as a divinely ordained duty, and given that voluntary giving in the forms of sadaqa (meritorious giving to the needy) and waqf (pious endowment) have a long and significant history in Muslim-majority societies, the relative dearth of scholarly analyses of Muslim philanthropy gives reason for pause. ${ }^{2}$ Is charity such a ubiquitous Muslim practice that scholars have taken it for granted? Is it so pervasive that it has not required systematic study? In tackling these questions, I focus on the scholarship on Islam in the United States, and I use philanthropy and charity interchangeably while recognizing that most scholars of philanthropy do not consider the two synonymous. As Robert Payton and Michael Moody explain, philanthropy differs from charity in that it aims to make systematic changes "to improve the quality of life" of people less fortunate whereas charity works "to relieve suffering" that results from an immediate need (Payton \& Moody, 2008, p.38). This distinction, however, does not map directly onto Islamic practices of zakat, sadaqa, and waqf. It is important to be mindful of them so as not to indiscriminately map onto Islam academic notions of charity rooted in nongovernmental organizations and Christian understandings of charity.

As religious acts subject to God's judgment, zakat, sadaqa, and waqf could be employed to both improve quality of life and relieve suffering, depending on one's interpretation of what constitutes a need that demands a religious response. In the case of zakat - traditionally construed as a divinely ordained obligation to give a specified percentage of one's wealth to specific groups - another important consideration is whether or not other Muslims, particularly legal scholars (ulama) who strive to interpret God's will for humanity, would also consider one's choice of charitable giving as fulfilling God's command. This question has come up for many U.S. Muslims in relation to contributions to nonprofit organizations that advocate for Muslim rights, particularly in the aftermath of 9/11. Do these contributions fulfill zakat obligations according to Islamic law? To address this concern, Muslim rights organizations have asked Muslim scholars for their learned opinions (fatawa). The Council on American-Islamic Relations (CAIR), for example, cites an opinion by Sheikh Ahmad Kutty from the Islamic Institute of Toronto and asserts that

[n]umerous Muslim scholars have confirmed that Zakat is payable to organizations that exist to serve the Muslim community by protecting their rights. This is because work done

2 Some noteworthy studies of Muslim charity and philanthropy include Sabra (2000); Bonner, Ener, and Singer (2003); Singer (2008); and Amelia (2013). For Muslim philanthropy in America, see Siddiqui (2013) and Siddiqui (2010). 
by CAIR (and other such organizations) can be classified as fi-sabilillah ["in the path of God"], which is one of the eight categories of Zakat recipients detailed in the Quran (Chapter 9, Verse 60). (Council on American- Islamic Relations, 2015, emphasis theirs)

Thus, in the contemporary context of rising anti-Muslim sentiment where Muslims fear for their civil rights, zakat could be employed not only to alleviate an immediate need but also to effect systematic change in people's lives. Similar questions are raised about whether or not zakat could be used to build mosques or Islamic schools in the United States, and in each case individual Muslims answer these questions based on a combination of their personal understanding of what God demands of them, what Muslim scholars say about the matter, and the laws and customs of their local community.

In other cases, we find U.S. Muslims giving, not because they are trying to alleviate a need, but because they deem the act of giving meritorious in the eyes of God. One of the clearest and earliest examples of this occurs among Muslim slaves who, in the nineteenth century, distributed saraka ${ }^{3}$ in the form of small cakes to children on plantations off the coast of Georgia. This act was both frequent and memorable enough that decades later, in the 1930s, their grandchildren recounted the rituals surrounding its distribution to ethnographers of the Works Progress Administration (WPA). Shad Hall, for example, recalled that his grandmother, Hestuh,

make strange cake, fus ub ebry munt. She call it "saraka." She make it out uh meal an honey. She put meal in bilin watuh an take it right out. Den she mix it wid honey, and make it in flat cakes. Sometimes she make it out uh rice. Duh cake made, she call us all in an deah she hab great big fannuh full an she gib us each cake. Den we all stands roun table, and she says, "Ameen, Ameen, Ameen," an we all eats cake (Granger, 1940, p. 159).

In the antebellum South, where slaves were stripped of any wealth as well as ancestral and religious ties, the distribution of saraka cakes became a means of entering into communal relations through a praiseworthy act in Islam rather than a form of charitable donation to the needy. ${ }^{4}$ This distinctive practice of saraka among West African Muslims enslaved in the United States is similar to instances of the practice of nadhr found in many Muslim-majority societies. Nadhr is a personal vow to fulfill a pious act in exchange for God or a saint fulfilling one's supplication. It often involves the distribution of food to the poor or to visitors to a shrine. ${ }^{5}$ Although those who practice nadhr often vow to perform a charitable act involving food, their primary objective in taking such a vow is not necessarily charity. Rather, it is to receive divine assistance.

The preceding examples demonstrate how deeply charity and philanthropy are embedded in Islam and Muslim societies, but also how Islamic notions of zakat, sadaqa, nadhr, and waqf have distinct connotations and social implications that are not always in accord with notions of service, voluntarism, and the public good commonly associated with philanthropy. The

According to Sylviane Diouf, saraka was the pronunciation of the Arabic word sadaqa used by the Malinke of Guinea and the Hausa of Nigeria, and members of both of these ethnic groups were found among slaves on the plantations of the Georgia Sea Islands. See Diouf (1999, p. 27).

$4 \quad$ For an excellent discussion of communal dimensions of sadaqa in West Africa, see Launay (1992, pp. 211-218).

$5 \quad$ See Singer (2008, p. 76) for a discussion of nazr in Afghanistan. 
characterization of philanthropy in the contemporary United States as other-directed, voluntary, and for the public good has its roots in Christian notions of caritas, or selfless love of others, from which the English word "charity" is derived. In Islam, zakat may be self-regulated and require sacrificing one's wealth, but its purpose is not defined by voluntarism. It is a religious obligation that is subject to divine reward and punishment. Though nadhr is a vow to perform a pious act often involving charity, it is not obligatory, nor is it necessarily selfless. There are also times when sadaqa is performed as a meritorious act in and of itself regardless of whether it actually alleviates a need or contributes to the public good. Waqfs are endowments that support institutions for what may be typically construed as the charitable and religious purposes associated with Western concepts of philanthropy. But they also serve as financial trusts through which patrons could shelter their wealth and assure the financial security of their own families or loved ones. This is usually done by stipulating a salary for members of one's family from the waqf in exchange for their management of the assets associated with it. Although subject to abuse, the fact that the family waqf, or al-waqf al-ahli, is designed for the benefit of kin makes it no less an act of charitable giving by traditional Islamic norms. Indeed, one of the "attributes" (sifat) that classically qualifies a group to receive zakat is that its members be among one's familial relations. ${ }^{6}$ In sum, although the nature and telos of each of these Islamic practices of giving vary, they all function in establishing relations between different individuals and social groups.

\section{The Polyvalence of Muslim Practices of Giving}

By calling attention to these distinctive implications of charity in Islam, I do not mean to suggest that Muslim philanthropists do not value altruism, voluntarism, or the public good. Quite the contrary. In fact, there is no doubt that these values have played an influential role in how Muslims have decided to pay zakat, give sadaqa, make nadhr, or establish waqfs. I also do not intend to revive the unhelpful dichotomy between Islam and the West by juxtaposing so-called "Islamic" and so-called "American" conceptions of charity. It goes without saying that, in practice, not all instances of non-Muslim philanthropy in the United States are other-directed, voluntary, and for the public good. Rather, by highlighting the distinct colorings of philanthropy in Islam, I hope to illustrate that, although most Muslims agree that charity is a divinely ordained obligation, there is no single Islamic conception of charity or philanthropy. At the risk of stating the obvious, the critical point here is that Muslims interpret Islamic values differently, and it is these differences that have made charity a polyvalent practice in the innumerable and varied social contexts of Muslim life.

Unfortunately, the polyvalence of Muslim identity and practice, albeit colorfully visible in cultural expressions, has generally been muted in public discourses on Islam. Such discourses, even among Muslims themselves, rarely conceptualize Islam as a dynamic tradition through which Muslims attempt to address an entire spectrum of challenges - especially those posed by modernity — as do their non-Muslim counterparts in the "West." According to this view of Islam and modernity, because nearly all Muslim-majority societies in the modern era came under some sort of political or economic subjugation at the hand of European empires, most Muslims were

Abu Hamid al-Ghazali, for example, enumerates as his "sixth quality" of the proper recipients of zakat: "that they be among one's close relatives or distant kin" (an yakuna min al-aqarib wa dhawi l-arham). See al-Ghazali (1405 AH/1982 CE, p. 95). 
introduced to the political, technological, and scientific advances associated with modernity at the same time as Muslim states lost political autonomy. Consequently, public discourses on Islam have generally conceived of modernity as a problem for Muslims, and students of Islam have generally concerned themselves with how Muslim elites have addressed the question of Euro-American dominance in the world while overlooking the religious question of how Muslims have interpreted Islam in their daily lives. Questions, for example, about how individuals practiced charity or paid zakat under colonial rule or in post-colonial nation-states have not been deemed as important as questions surrounding the rise of so-called Islamist movements in the modern era.

This neglect of everyday religious practices has been further sustained by the widespread notion that there is no distinction between religion and politics in Islam as there is in secular modernity. Because the prophet Muhammad b. 'Abd Allah (d. c. 11/632) founded both a religion and a polity through his teachings, it has generally been assumed that Muslim political and religious history are one and the same. This notion has been so widespread that in his influential book Islam in Modern History, Wilfred Cantwell Smith felt it necessary to offer a lengthy defense of his approach to Islam as a "faith." He argued that Islam not only shapes social and political institutions but also affects an individual's worldview and personal relation to God (Smith, 1957, pp. 7-12). However, despite challenging conventional approaches to Islamic history as the history of Muslim politics by focusing on Islam as a "faith," even Wilfred Cantwell Smith associated modernity with a "very serious decline" in Islam and attributed this decline to Muslims' loss of military and political power to European states. He wrote that, at the onset of the modern era,

Muslim society was losing its once firm, proud grip on the world. Moreover, it so happened that this degeneration coincided with the exuberance of Europe. At about this time Western civilization was launching forth on the greatest upsurge of expansive energy that human history has ever seen. Vitality, skill, and power vastly accumulated. With them the West was presently reshaping its own life and soon the life of all the world. This new giant, striding forth in exploratory restlessness, met the Muslim world and found its own growing might confronted with growing infirmity (Smith, 1957, p. 38).

One of the consequences of conceptualizing modernity as a political crisis for Muslims has been that, up until recently, scholarship on modern Islam did not focus on Muslims as creative agents engaging modernity on their own terms. Rather, as Smith's quote illustrates, it focused on Muslims as subjects who reacted to a world shaped by a politically and militarily dominant EuroAmerican culture, commonly referred to as "the West."7 This view of Muslims shaped the study of Islam in the United States and has led many scholars to look for sources of friction in U.S. Muslim experiences, rather than seeing Muslims as one of the many agentive participants in a religiously, culturally, and racially diverse America. From such a politicized vantage point, quotidian activities associated with Islamic practices such as prayer, fasting, and charity were rendered invisible despite their immense importance in orienting Muslims spatially, temporally, and socially.

I should note that Smith was one of the early critics of the notion that Islam is "inert, the passive recipient of [Western] influence." Nonetheless, as the above quote demonstrates, he did not see Muslims as participants in the making of a modern world. Rather he saw the "thrust of Islam in this situation" in "the dynamics of its reaction...to the modern world" (1957, p. 14, emphasis mine). 


\section{Rendering Muslim Giving Academically Invisible}

The field of comparative religion furnished another set of blinders to the practice of Islam in the latter half of the twentieth century through its operative premise that homo religiosus was the only religious subject of any sociological or historical import in an increasingly rationalistic world. ${ }^{8}$ The comparative study of religion through the lens of homo religiosus reduced religions to the experience of the "sacred." It operated under the assumption that as empirical reasoning became the basis of modern social, economic, and political structures, the study of institutions and rituals based on religious notions of the supernatural was of secondary importance to individual's private experiences of the transcendent. The former was seen to conflict with modernity, whereas the latter was believed to accommodate it by rendering the religious to the private realm. Religious differences embodied in institutions, customs, laws, and rituals were seen as derivatives of manifestations of the sacred experienced by humans, which could be best understood symbolically rather than through history and social scientific study. From this point of view, the only religion that mattered was the one based on an internal feeling or experience of the sacred. Thus the social and political embodiment of religion in institutions and rituals as well as in social concepts such as race, gender, and class were pushed out of sight. They were replaced by a sacred-profane binary that regarded the physical and the socio-historical as profane or "unreal" and defined the sacred or "the real" in terms of an immanent and eternal self-manifestation of the divine, which homo religiosus experienced internally and secondarily expressed symbolically through religious texts and rites. ${ }^{9}$

In this view of religion, which remains enormously influential in American culture despite numerous critiques from within the academy, ${ }^{10}$ charity was not considered a significant act in and of itself but a positive, outward consequence of internal religious sentiments. William James famously defined it in Varieties of Religious Experience as "a usual fruit of saintliness," (James, 1902, p. 306) or more specifically, as one of the "practical consequences" of a "fundamental inner condition," which he described as "a shifting of the emotional centre towards loving and harmonious affections" toward others (pp. 299-300). Feelings, which following liberal theological understandings of charity, he asserted, "follow logically from the assurance of God's friendly presence, the notion of our brotherhood as men being an immediate inference from that of God's fatherhood of us all" (p. 306). In other words, James explained that charity is an "organic consequence" of faith or a feeling of being in unity with something greater than oneself that fosters

8 The most notable and influential proponent of this idea in the United States was Mircea Eliade. See in particular The Sacred and the Profane (1959) in which he builds on the controversial tradition of Rudolf Otto's attempt (Otto, 1917/2010) to articulate sui generis categories for what ironically was intended to be a non-reductionist critical study of religious experience in the context of the modern Western academy.

9 In the latter half of the twentieth century, in addition to Mircea Eliade, these ideas were popularized in the United States through the works of scholars such as Joseph Campbell, Seyyed Hossein Nasr, and Huston Smith.

10 By way of example, see Smith (1987); Wasserstrom (1999); McCutcheon (1997); Shaw (1995); and Fitzgerald (2003). 
happiness, sympathy, and kindness in individuals, a form of other-directed "healthy-mindedness... which looks on all things and sees that they are good" (pp. 101, 307).

James identified religious interiority that resulted in healthy-mindedness as "genuine religion." Genuine religion fostered individual happiness, but James was too much of an empiricist and too careful of a scholar to whitewash all religion as happy. He also realized that religious people do bad things and are often unhappy. He argued,

The basenesses so commonly charged to religion's account are thus, almost all of them, not chargeable at all to religion proper, but rather to religion's wicked practical partner, the spirit of corporate dominion. And the bigotries are most of them in their turn chargeable to religion's wicked intellectual partner, the spirit of dogmatic dominion, the passion for laying down the law in the form of an absolutely closed-in theoretic system. The ecclesiastical spirit in general is the sum of these two spirits of dominion. (James, 1902, p. 370)

He went on to beseech his reader not to confuse the "tribal or corporate psychology" presented by the church with "the purely interior life," which he defined as religion (p. 370).

More recently, the popular New York Times columnist David Brooks evoked William James's Varieties of Religious Experiences to argue that President Obama "is clearly wrong when he refuses to use the word 'Islam' in reference to Islamist terrorism." In deciding whether or not to call acts of political violence undertaken by certain individual Muslims "Islamic," Brooks argued that it is useful to keep in mind the distinction James made between "genuine religion" and its "wicked practical partner, the spirit of corporate dominion." According to Brooks, James's work clarifies "the core of our confusion... about what a religion is" (Brooks, 2016). Shadowing the association of religion with interiority in the early study of comparative religion, Brooks explains,

It seems blindly obvious to say, but the spirit of religion begins with a sense that God exists... and out of that flows a set of values and experiences: prayer, praise, charity, contrition, grace and the desire to grow closer toward holiness.... The spirit of dominion... does not start with an awareness of God. It starts with a sense of injury and a desire to heal injury through revenge and dominion. (Brooks, 2016, p. A29)

In other words, the terrorist's religion is not "healthy-minded." For Brooks, such "religion" associates injury with "some external enemy... rather than internal weakness." And at this point, political ideology enters into religion and "gives the injured a course of action that will make them feel grandiose and heroic" (Brooks, 2016). From this, it logically follows that insofar as one could detect "the spirit of dogmatic dominion, [and] the passion for laying down the law" among even a few Muslims, violent acts carried out by groups like al-Qaeda or the Islamic State may justifiably be called "Islamic," even though they cannot be called "genuinely religious."

It is important to note that in making his argument, Brooks did not concern himself with what Muslim practices reveal about religion. He did not inquire into the voluminous discourses in the Islamic tradition about violence, happiness, charity, God, or divine union. His concern, as well as the concern of most of his readers, was to explain how Islam fits into the prevailing idea that "good religion" is essentially an internal experience of the sacred that reconciles the individual with the sociopolitical and economic structures that impede their happiness. Indeed, in the 
contemporary United States, to the extent that Islam does not fit comfortably into this conception of religion - a conception that effectively defines "good" religion as one that accommodates, and even defers to, the power of the sovereign secular nation-state - it has been pathologized. It is thus no wonder that more energy and time have been spent identifying the pathologies of Islam in the modern era than examining how millions of Muslims practice their religion.

\section{Pathologizing Muslim Philanthropy as Politically Subversive}

A telling example of pathologizing approaches to Islam in discussions of Muslim philanthropy after 9/11 is found in J. Millar Burr and Robert O. Collins's (2006) Alms for Jihad:

In ["Western"] Christian countries institutions seeking financial support for charitable activities have discreetly segregated the secular from the religious, reflecting the historic separation of church and state.... In contrast, Islam does not distinguish between church and state. Muslims who are obligated to perform zakat and individual donors make no distinction between the secular and religious uses to which their donations may be employed. That allows those who administer Islamic charities a great deal of latitude as to how the money is spent and for what purpose. (Burr \& Collins, 2006, pp. 6-7)

The specific purpose that Burr and Collins have in mind is religious militancy and terrorism, and they rely on above-discussed preconceptions to identify its pathology in Islam. They further rely on their readers sharing in the facile assumption that religion and politics are one and the same in Islam and that, historically, while so-called Christian societies modernized, Muslimmajority societies stuck to tradition. Their pathologizing approach to Islam results in their identification of a doctrinal Muslim practice, zakat, as a possibly nefarious source of funding for terrorism, irrespective of the way individual Muslims decide to practice zakat. From such a dubious perspective, all acts of Muslim charity are suspect. Either Muslims naively fulfill an obligation that terrorists could then hijack for their own purposes or they knowingly contribute to militant causes in the name of charity because they do not make a distinction between religion and politics. Whichever of these views one takes, neither recognizes the creative agency exercised by Muslims as they attempt to critically engage their sociopolitical circumstances through charitable giving.

This pathologizing approach to Islam also informed the U.S. government's early reactions to the attacks of 9/11. A few days after the attacks, President George W. Bush ordered the Treasury Department to freeze the assets of 27 not-for-profit entities that the government considered to be "fronts for terrorism." Among these were the three largest U.S. Muslim relief organizations: the Holy Land Foundation for Relief and Development, the Global Relief Foundation, and the Benevolence International Foundation. "Just to show you how insidious these terrorists are," President Bush warned U.S. Americans, "they often times use nice-sounding, non-governmental organizations as fronts for their activities." He went on to explain that the government had "targeted" this pathological use of charity and was working to freeze and block the use of their assets both in the United States and abroad (Bureau of Public Affairs Department of State, 2001). The decision to freeze the assets of three of the largest Muslim charities in the United States rather than require them to demonstrate unequivocally the legal use of their donations for charitable purposes is a telling sign of the depth and consequences of the pathologizing approaches toward 
Islam that are still pervasive today. The targeted Muslim charities were treated as monolithic entities and stigmatized as sources of contagion that needed to be contained, rather than as civic institutions of sociopolitical agents subject to their national context and donor base-agents who could respond dynamically to changing circumstances and government regulations.

Another telling sign of the depth and consequence of pathologizing approaches to Islam after 9/11 was present in the treatment of the remittances U.S. Muslims of immigrant backgrounds sent to friends and families in their native lands. Similar to their non-Muslim counterparts, most Muslim immigrants came to the United States in search of what they hoped would be a better life. Because many of them have achieved relative success, they have felt an obligation to help their less fortunate family members and friends "back home." Because some of these Muslim immigrants are from countries that are impoverished or in political turmoil (oftentimes a primary reason for their emigration to the United States), their family and friends do not always have easy access to the international banking system. For this reason, like many non-Muslim immigrants from similar backgrounds, they rely on informal financial networks to remit money to support loved ones in their native countries (GhaneaBassiri, 2010, pp. 166-167). This common practice among immigrants from poor or politically unstable countries, however, was painted negatively in the media and state discourses as a "Muslim" practice susceptible to nefarious use. This was done by referring to it by its Arabic name ${ }^{11}$ as hawala rather than simply as "remittances," thus obfuscating its purpose and bringing suspicion to anyone associated with it. ${ }^{12}$

\section{Interpreting Zakat in Response to State Pressure}

It is noteworthy that U.S. Muslim activists did not initially respond to the government's targeting of international Muslim relief efforts by portraying themselves as victims of the political system. They depicted the government's actions as a by-product of the public's ignorance of Muslim practices and Islamic values and, in some cases, of "Zionist" opposition to Muslim political interests (Ameri, 2004). In general, they regarded the U.S. political system as fair and subject to change (Skerry, 2006). They saw themselves as one of the latest links at the end of a long chain of minority civil rights struggles in U.S. history. They insisted that "American and Islamic values can intertwine," and that U.S. Muslims should see it as their civic and Islamic responsibility to use their unique "opportunities of freedom and success to help the needy and poor in the United States and other countries" (Ameri, 2004).

This interpretation of the government's actions toward Muslim charitable giving did not directly challenge the pathologizing of Islamic beliefs and practices as potentially subversive, though it did enable Muslim activists to engage government officials on familiar grounds. Whether this was a case of political pragmatism or an instance of self-disciplining in the face of state power is debatable. What is clear is that - or at least a few years after 9/11, when government officials

11 This is a subtle but highly effective strategy for "othering" Muslim instances of a practice undertaken by countless non-Muslim citizens from immigrant backgrounds-most notably Mexican Americans.

12 For examples of media reports on hawala shortly after 9/11, see Girth and Miller (2001); Day (2001); McKinnon, Chorney, and Carnig (2001); and Frantz (2001). For an example for governmental discussion of hawala in relation to terrorism, see Jost and Sandhu (2000). Also see Burr and Collins (2006, pp. 71-75). 
and the public more generally looked to Islam through the lens of pathology, and especially "terrorism," and deemed Muslim charitable giving suspect-most leading U.S. Muslim organizations did little to challenge the state's logic. Rather, they sought to work with the government by asking the Treasury Department to clarify its conception of what constituted sound charitable practices. U.S. Muslim activists organized nationally to urge the government to put together a list of Muslim charities to which Muslims could donate without worrying about the government confiscating their donations or worrying that they themselves might become a target of the state (Al-Marayati, 2004). They also asked the Treasury Department to issue guidelines based on which Muslim charities could operate securely and thus assure that their donations would not end up in a government-frozen account, or in the pockets of pricey lawyers (Ameri, 2004). The Holy Land Foundation had even approached government officials prior to 9/11 for help in complying with the law, but was rebuffed (Turner, 2009). KindHearts reported that, in December 2003, it formally appealed to testify before the Senate Finance Committee to explain its activities and the transparency of their finances. They did not receive a reply and had their funds frozen in February 2006 (Bafaquih, 2006).

Overtime, the government's reluctance to provide concrete guidance ${ }^{13}$ or to directly engage with Muslim leaders became an impetus for activists to challenge the logic of its actions. They argued that they faced a "fishing expedition" or "witch-hunt" that unconstitutionally expanded the powers of the government and impinged on Muslims' rights to free exercise of their religion (AlMarayati, 2004). Noted U.S. Muslim lawyer and scholar of international human rights law, M. Cherif Bassiouni, called the government's actions an "assault upon constitutional freedoms under the guise of terrorist-related prosecutions" and a "fear-mongering campaign... supported by avowedly anti-Muslim groups" (Bassiouni, 2008). There was a general sense among U.S. Muslim activists specifically, and civil rights groups more generally, that

[t]he government's actions have created a climate of fear that chills American Muslims' free and full exercise of their religion through charitable giving, or Zakat, one of the 'five pillars' of Islam and a religious obligation for all observant Muslims. (Turner, 2009, p. 6)

Not unlike earlier responses to the closing of Muslim charities-responses which did not directly challenge the logic of state power and were presented in the familiar bureaucratic language of U.S. political culture-later civil rights arguments against state overreach were also presented in terms of political values and presuppositions about Islam and religion that were familiar to the public. This point is illustrated in the 2008-2009 interviews with select U.S. Muslims that the American Civil Liberties Union cited to proffer evidence of the chilling effect the government's actions have had on the free exercise of religion.

I feel this is part of my religion, part of my faith: that I have to help through donation, to needy people in Palestine or Bangladesh, people living in war or occupation, people suffering a disaster like an earthquake. Now I can't make donations-it's clear to everybody you can't give to Muslim charities... Since HLF [the Holy Land Foundation] was closed, now there is no way to give in a way that is clearly legal. We don't know how

13 As I discuss below, the government did respond to these requests by issuing broad voluntary guidelines that international charities and foundations found too general to be applicable. 
to give now, and there is no way to give Zakat now.... Right now I am not giving, I have halted my Zakat, and this means I am not complying with my religion. Even international law says I can help people in need according to my religion. (Turner, 2009, p. 89)

Before I was giving to any Muslim charities that help the Muslim community, if it was a humanitarian organization. There were a couple of good ones, but the government shut them down and named them terrorist organizations. Now we are scared to give to any. After what we're seeing from the Bush administration, and too many innocent donors being questioned, I just stopped. I'm not giving anymore. (Turner 2009, p. 91)

While it is understandable that a Muslim who donates to international Muslim relief organizations may fear doing so after the government precipitately shuttered some of them for allegedly supporting terrorism, it is not at all clear why these actions would impede Muslims from fulfilling the obligation of zakat by giving to the needy in general. After all, needy Muslims did not suddenly disappear from the United States. Couldn't U.S. Muslims personally find needy individuals or charitable causes for their zakat? This is, in fact, a technical possibility in Islamic law, which recognizes the right of a legitimate Muslim ruler to collect and distribute zakat according to Islamic law but does not release individuals from the obligation of zakat in the absence of such a ruler, permitting them to pay zakat directly to the needy or to another organization that could be trusted to distribute it properly. ${ }^{14}$

Now, given that individual Muslims can technically distribute their own zakat money to the needy, it seems safe to assume that those who argued that the government's closing of Muslim charities created "a climate of fear" that "made it impossible for [Muslims] to fulfill their religious obligation" (Turner, 2009, p. 9) did so with its political effects in mind; they sought to protect U.S. Muslims from state intimidation. Furthermore, they argued within a conceptual framework more resonant with U.S. legal and civic discourses than with Islamic law. As such, they indirectly reinscribed presuppositions about the inflexibility and doctrinaire nature of Islam as well as about the essentially private nature of religion. Consequently, clunky arguments were put forth that made little sense in terms of the normative practices of charity in Islam, which in fact afford Muslims measured flexibility in giving their zakat, but were perfectly sensible in the political culture of the United States and its paradoxical understandings of Islam as rigidly zealous and of religion as interiorized and private.

For six years I really have not been able to fulfill Zakat.... HLF was in the news and they painted all the Muslim charities with a very broad brush; for a very long time we haven't known what charity we could trust to give to.... It is an obligation we have as a Muslim: you have to pray, you have to go on Hajj, and you have to give Zakat if you can afford it. This is all part of being a Muslim, and we absolutely have not been able to practice our religion to the extent we are obligated to do so. This is why the Pilgrims sailed here, for religious freedom. I don't have any religious rights anymore; I ask am I living in America? It is disheartening, disappointing. I feel that I sinned. (Turner, 2009, p. 14)

14 The history and legal opinions surrounding zakat payments are complicated and vary by region and era. For a learned overview, see Singer (2008, pp. 44-62). 
Another interviewee, echoing William James's association of charity with healthy-minded spirituality, argued, "Closing down the charities, you are getting to the spiritual essence of the human being. Every person needs to give to charities as a religious obligation, to feel good as a person, and the government has closed this off' (Turner, 2009, p. 91). The notions that one cannot pay zakat if a specific set of international relief organizations are not accessible or that charity is related to the spiritual essence of humans may be dissonant with the notion of charity as a divinely ordained obligation in Islam, but they nonetheless echo American political sensibilities and Protestant theological understandings of freedom of conscience.

As political scientist Peter Skerry (2006) notes, "Muslims never sound quite so American as when asserting their rights against government policies they consider unjust." By interpreting Islamic practices in the language of U.S. democratic values, U.S. Muslim activists gained a partial hearing from both the non-Muslim public and government officials. Writing in The Chronicle of Philanthropy, the executive director of the Ohio Association of Nonprofit Organizations admonished the industry for its "silence" on Muslim charities:

The implications for Muslim charities are already being felt and are disturbing. No list of "clean" organizations - those organization not under governmental investigation - exists, creating a chilling effect on donations to all Muslim organizations, especially those that work overseas.... It may not be appropriate to express outright support for the Muslim organizations that have been shut down as part of the government's war on terrorism, but America's nonprofit leaders should be paying attention, and should express some concern about the issues of due process, accountability, and fair treatment raised by these cases. (Moyers, 2002)

The Department of Treasury sought to respond to these concerns expressed by U.S. Muslim activists and industry leaders by issuing in 2002 a set of voluntary "anti-terrorist financing guidelines" for U.S.-based charities. Charities and foundations, however, criticized these guidelines because of the heavy investigative burden they placed on charities and foundations. The guidelines required charitable organizations to collect a broad range of information on the financial practices and accounts of their grantees (Council on Foundations, 2003). Later in 2004, the Treasury Department asked charities and foundations for advice on drafting voluntary guidelines for U.S.-based charities. This process led to a revised set of guidelines issued in 2005 (Williams, 2004). In June 2004, the Treasury also appointed Mahmoud el-Gamal, a professor of economics at Rice University, as the first Islamic Finance Scholar-in-Residence to assist it with better understanding Islamic financial practices (Reuters, 2004). The Obama administration advanced efforts to work with domestic Muslim organizations. In his widely publicized 2009 Cairo University speech to the global Muslim community, President Obama validated U.S. Muslim activists' concerns about the consequences of the government's treatment of Muslim charities for Muslim civil and political rights and responded to their request for collaborations:

Freedom of religion is central to the ability of peoples to live together.... For instance, in the United States, rules on charitable giving have made it harder for Muslims to fulfill their religious obligation. That's why I'm committed to working with American Muslims to ensure that they can fulfill zakat. (Obama, 2009) 


\section{A New Dialectic: Flourishing between Alienation and Resistance}

Those who pathologized Islam targeted Muslim charities with the stated intent to contain the threat of terrorism. Meanwhile, those concerned about civil rights saw contagious symptoms of government overreach in the fear American Muslims felt after 9/11. Although these two camps often stood in political opposition, both politicized American Muslim philanthropy and further contributed to the highly problematic securitization of U.S. Muslim identity ${ }^{15}$ by framing the government's actions against Muslim charities in terms of balancing national security with religious freedom. This framing of Muslim charitable giving as a problem for U.S. Americans' security and liberty does not reflect the reality of U.S. Muslim philanthropy post-9/11, but there is no denying that it has had real consequences by securitizing international relief work in the United States and bringing U.S. Muslim activists into conversation with the state as intermediaries who could help balance the presumed conflict between national security and religious liberty.

Muslim philanthropy in the United States after 9/11 belies Muslim charity as a problem for security and liberty. On the whole, U.S. Muslims never stopped giving to charity in response to the government's investigation and prosecution of the largest U.S. Muslim international relief organizations. In reality, U.S. Muslims gave in larger numbers and diversified their donations by giving to non-Muslim charities and rights organizations, to local U.S. Muslim non-profit organizations, and to smaller regional charities in their home countries. U.S. Muslim philanthropists donated to universities to establish chairs and centers for Islamic Studies. ${ }^{16}$ The annual budget of the Chicago-based Inner-City Muslim Action Network (IMAN), which fights poverty and other forms of structural injustices in inner-city neighborhoods, increased from $\$ 200,000$ to $\$ 2$ million after 9/11. More U.S. Muslim philanthropic dollars also went to Muslim rights organizations. Donations for the construction of mosques, Islamic schools, and community centers increased (Hartman, 2011). Donations to major relief organizations also never ceased. In fact, they seem to have increased significantly. As Shariq Siddiqui's (2013) research has shown, charitable giving to the 14 largest American Muslim relief organizations "rose from a little more than \$29 million in 2002 to more than \$96 million in 2008."

And despite its drawbacks, framing Muslim charity in the language of national security and religious freedom resulted in the securitization of U.S. Muslim charities and led U.S. Muslim rights organizations to become conciliators between Muslim nonprofits and governmental bureaucracies. So what does the latent realization that, in practice, U.S. Muslims never stopped giving to charity reveal about the role of Muslim philanthropy in the United States? What is learned by focusing on the actual practice of Muslim philanthropy in the United States rather than its politicization by the government and U.S. Muslim activists?

First and foremost, it is clear that the average U.S. Muslim practiced zakat according to the principles of Islamic law, which do not necessitate zakat to be paid to any particular institution. They did not stop giving zakat money to charitable causes in the face of intimidating state tactics. Furthermore, the select Muslims cited by the ACLU withstanding, most U.S. Muslims did not subjugate their obligation to pay zakat to politics; they did not stop paying zakat in order to proffer evidence for civil rights organizations to argue against government violations of U.S. Muslims'

15 For a discussion of this issue, see Mandaville (2013) and Fox and Akbaba (2015).

16 A significant example of this is the Abbasi Program in Islamic Studies established at Stanford University (Delevett, 2003). 
First Amendment rights. In spite of the politicized din surrounding Muslim philanthropy in the United States after 9/11, the average Muslim did not lose sight of the fact that the needy and philanthropic causes did not disappear because of the U.S. government's intimidating actions. When local exigencies prevented them from giving to certain charities, they fulfilled God's command by giving to others.

Structurally, beyond the choices made by individual Muslims about how to give to charity, U.S. Muslim philanthropy post-9/11 has been consonant with the general role philanthropy plays in the broader civil society, fulfilling needs that the state cannot or fails to address. A pertinent illustration of this form of U.S. Muslim philanthropy is the establishment of free health clinics and the contributions made toward organizations such as IMAN. Furthermore, by financially helping U.S. Muslims develop new support networks or strengthen existing ones, U.S. Muslim philanthropy has functioned as a means of resisting state policies and public discourses that targeted Muslims and stigmatized Islam in general. These support networks were bolstered by charitable donations to Muslim civil rights organizations, such as the Council on American-Islamic Relations, and to community-building efforts, such as the construction of mosques, schools, and Muslim community centers. The sociological consequence of this community-bolstering philanthropy was that it provided a marginalized minority community a means of resisting oppressive state actions and stigmatizing public discourses, while at the same time becoming more deeply invested in American social and political structures.

It could then be said that-in practice-U.S. Muslim philanthropy post-9/11 has maintained a productive tension between alienation and resistance on the one hand and assimilation and accommodation on the other. The diversification of U.S. Muslim philanthropic activity after $9 / 11$ is partly the result of this tension, which has provided Muslims the sociopolitical space to act decisively and varyingly as U.S. citizens and Muslims. This resulting space between alienation and assimilation, and between resistance and accommodation, has allowed Muslims to integrate their individual and communal needs and religious values into a productive dialectical relationship with U.S. civic norms and political principles. The polyvalence of Muslim practices and the relative flexibility of interpretation that the Islamic tradition affords its adherents have enabled these dialectical relations, and they have, in turn, pushed U.S. Muslims into social relations of care with people of widely varied cultural, political, religious, and economic backgrounds. These various groups have not all agreed on what constitutes the greater good to which people should give. There is no doubt, for example, that despite their mutual engagement at various points, the state and U.S. Muslim relief organizations have not seen eye to eye. Nonetheless, giving, in and of itself, based on varying understandings of Islamic values has forged social relations that are shaping both U.S. Muslim religious identities and modes of communal belonging. According to a Muslim American civil engineer working with the U.S. military's U.S. Disaster Assistance Center during the 2005 Kashmir earthquake,

One of the many rewarding parts of this trip was the coordination effort between the different groups of people in Pakistan. Everyone was there for the same reason - to help in whatever capacity they could.... For me, as a Muslim American (Pakistani), it was comforting to see the Pakistani and American military work hand in hand.... How ironic to feel such warmth and unity in the midst of such tremendous destruction and devastation. (Khan, 2006) 
Focusing on the practice of philanthropy reveals both the diversity and the critical nature of American Muslims' engagement with American society and politics. At the time of this writing, American Muslims are in alliances with social justice and civil rights organizations through financial support of organizations critical of U.S. policies and society, such as Black Lives Matter and the ACLU. There are also U.S. Muslims whose sizable donations to the two major U.S. political parties have provided individual Muslims access to political insiders. In the case of the Republican Party, it has even afforded individual U.S. Muslims meetings with figures like Donald Trump and Newt Gingrich who have promoted a ban on Muslim immigration and have advocated anti-Shari'a legislation ("A Muslim at the RNC," 2016).

At a more organized level, in the aftermath of Hurricane Katrina in 2005, several major Muslim relief organizations came together to form the Muslim Hurricane Relief Taskforce which pledged to raise $\$ 10$ million for Katrina relief effort. At a time when U.S. Muslim charitable giving was under suspicion, they sought to shape a different relation with the state and the public through philanthropy. They touted the taskforce's special "focus on financial transparency and accountability as set forth in relevant government regulations and standards." They also emphasized their relations to fellow Americans and the state as American citizens. The subtitle of a special report on Hurricane Katrina published in the most widely distributed American Muslim magazine of the time, Islamic Horizons, read, "Muslim Americans Rally to Help Fellow Citizens." The Secretary General of the Islamic Society of North America told the American public, "It is a national and Islamic obligation to assist one's neighbors when they are in need." At a time when national Muslim organizations were dealing with the government shutdown of Muslim relief organizations, his statement evinced U.S. Muslim organizations' awareness of how philanthropy forges relations between groups of varying political interests as well as between adherents of different religions. "Outside the mosque," Islamic Horizons reported, "a Christian mission from Dallas arrives and pulls the doors of a supply truck open and offers medicines to the needy victims at the mosque. And so it goes, Christian shelters and Muslim shelters intermingle their support" (Islamic Horizons, 2005a, pp. 1-2, 4).

The social relations that have been and can be forged through the dialectical tension that philanthropy maintains between resisting oppressive state practices and integrating into dominant sociopolitical structures is also evident in the work of the American Muslim Taskforce for Disaster Relief, which was formed in response to the devastating Kashmir earthquake of 2005. The work of this taskforce was also featured in a special report in Islamic Horizons, but its tone was expressly different. Rather than emphasizing national ties between citizens, the report emphasized religious ties between fellow Muslims as the report quoted the Prophet Muhammad saying, "Whoever relieves a believer of some of the distress of this world, God will relieve him of some of the distress of the Day of Resurrection." Furthermore, rather than seeking a new relationship with the government by emphasizing transparency and adherence to regulations, this report highlighted the opportunity U.S. relief efforts provide for the government to change its relations with people of a region who have been negatively affected by the George W. Bush administration's "war on terror." At a press conference held in Washington, DC, on October 12, 2005, the "[Kashmir earthquake] taskforce called on President Bush to appoint an ad-hoc committee of U.S. governmental and American Muslim non-governmental relief agencies to offer coordinated relief to earthquake victims." In a letter to the administration, the taskforce sought to drive home the point that through its relief efforts, the United States could form new relations with South Asian Muslims who have suffered adverse repercussions from the so-called "war on terror" and the U.S. invasion of Afghanistan. They argued, "Muslim humanitarian organizations know where the relief is needed 
the most and how it can be delivered in the most effective way. Hence, the partnership between the U.S. government and Muslim humanitarian organizations is vital to American interests. We are ready and willing to make the response to the South Asian earthquake disaster another shining example for America's goodwill and compassion" (Islamic Horizons, 2005b, pp. 1 - 4, 6 - 10).

\section{Conclusion}

In contemporary American public discourse, Islam is generally conceptualized as a doctrinaire religion whose adherents stand uncomfortably in relationship to modernity, whereas modern religion is generally conceptualized as a system based on internal experiences of transcendence that help individuals meet any structural challenges they face in life. Within the realm of these presuppositions, political acts of violence carried out by militant Muslim organizations, such as al-Qaeda, are generally seen as a consequence of Islam's incongruence with the values and structures of modernity. Many government officials and members of the public at large thus look to Islamic doctrines for explanations of Muslims' political acts of violence and for perceived solutions to the threat of terrorism. Such pathologizing approaches to Islam post-9/11 have focused on U.S. Muslim philanthropy as a possible source of funding for terrorism. The government's investigation and closing of several American Muslim international relief organizations have, in turn, raised questions about state violations of U.S. Muslims' constitutional right to practice zakat. Consequently, the public discourse on U.S. Muslim philanthropy post-9/11 has been framed by the perceived need to balance national security and religious liberty.

U.S. Muslims' actual philanthropic practices, however, contradict this framing of U.S. Muslim philanthropy. American Muslims, collectively, never stopped practicing zakat as a result of the actions the government took against the largest Muslim philanthropic organizations, nor have U.S. Muslim charities been shown to pose a threat to American national security. In contrast to general presumptions in U.S. public discourse about Islam's rigidity and religion's interiority, the actual practice of charity among U.S. Muslims highlights the polyvalence of Islam and the fluidity of the public practice of Islam. In the fluid space of practice, U.S. Muslims have brought Islamic vocabularies of charity and legal and sociopolitical norms regarding philanthropy in the United States into conversation with one another, and in doing so, they have forged and reconfigured relations across groups of varying social, religious, political, cultural, and economic backgrounds. In this process, they have shaped American Islam as multifarious and dynamic and have disclosed the profound variety of interpretations and motivations that underlie charitable giving in this country. 


\section{References}

A Muslim at the RNC. (2016, July 19). The Islamic Monthly. Retrieved from www.theislamicmonthly.com/a-muslim-at-the-rnc-2.

Ameri, N. (2004). Right to Zakat. Islamic Horizons, (July/August), p. 24.

Bafaquih, A.A. (2006). Zakat violated. Islamic Horizons, (May/June), pp. 28-29.

Bassiouni, M.C. (2008). Legal abuse fails. Islamic Horizons, January/February), p. 32.

Bonner, M., Ener, M., \& Singer, A. (Eds.). (2003). Poverty and charity in Middle Eastern contexts. Albany, NY: State University of New York Press.

Brooks, D. (2016, June 17). Religion's wicked neighbor. The New York Times, p. A29.

Bureau of Public Affairs Department of State. (2001, September 24). President freezes terrorists' assets. Retrieved from http://2001-2009.state.gov/s/ct/ rls/rm/ 2001/ 5041.htm

Burr, M., \& Collins, R. O. (2006). Alms for jihad: Charity and terrorism in the Islamic world. New York, NY: Cambridge University Press.

Council on American-Islamic Relations. (2015). Why CAIR qualifies for Zakat. Retrieved from www.cair.com/zakat.html.

Council on Foundations. (2003). Comments on U.S. Department of the Treasury anti-terrorist financing guidelines: Voluntary best practices for U.S.-based charities.

Curtis, E. (2013). The study of American Muslims: A history. In J. Hammer, \& O. Safi (Eds.), The Cambridge companion to American Islam (pp. 15-27). New York, NY: Cambridge University Press.

Day, K. (2001, November 7). U.S. Islamic cash outlets investigated: 'Hawalas' suspected in terror funding. The Washington Times, p. A1.

Delevett, P. (2003, September 20). Promoting study of Islam: Stanford plans program, professorship, thanks to huge gift from alumna. San Jose Mercury News, 1A.

Diouf, S. A. (1999). Sadaqa among African Muslims enslaved in the Americas. Journal of Islamic Studies, 10(1), pp. 22-32.

Eliade, M. (1959). The sacred and the profane. New York, NY: Harcourt, Brace \& World.

Fauzia, A. (2013). Faith and state: A history of Islamic philanthropy in Indonesia. Leiden, NL: Brill.

Fitzgerald, T. (2003). The ideology of religious studies. New York, NY: Oxford University Press.

Fox, J., \& Akbaba, Y. (2015). Securitization of Islam and religious discrimination: Religious minorities in Western democracies, 1990-2008. Comparative European Politics, 13(2), pp. 175197.

Frantz, D. (2001, October 3). A nation challenged: The financing; ancient secret system moves money globally. The New York Times, p. B5. 
GhaneaBassiri, K. (2010). A history of Islam in America: From the New World to the new world order. New York, NY: Cambridge University Press.

al-Ghazali, A. H. (1405 AH/1982 CE). Asrar al-zakat. A. A. Muhammad, (Ed.) Beirut:

Manshurat al-Maktabat al-'Asriyya.

Girth, J., \& Miller, J. (2001, November 5). A nation challenged: Money trail; U.S. makes inroads in isolating funds of terror groups. The New York Times, p. A1.

Granger, M. (Ed.). (1972). Drums and shadows: Survival studies among the Georgia coastal Negroes. New York, NY: Anchor Books_-Doubleday. (Original work published 1940)

Hartman, M. (2011, September 9). Muslim charitable giving shifted to domestic causes after 9/11. Retrieved from www.marketplace.org/2011/09/09/your-money/911-legacy/muslimcharitable-giving-shifted-domestic-causes-after-911

Islamic Horizons. (2005a, September). A special supplement: Hurricane Katrina, a national disaster: Muslim Americans rally to help fellow citizens.

Islamic Horizons. (2005b, November). A special supplement: A gigantic challenge: Muslim Americans rush to help South Asian earthquake victims.

James, W. (2002). The Varieties of religious experience: A study of human nature. New York, NY: The Modern Library. (Original work published 1902)

Jost, P. M., \& Sandhu, H. S. (2000). The Hawala alternative remittance system and its role in money laundering. Financial Crimes Enforcement Network in cooperation with

INTERPOL/FOPAC, n.d. Retrieved from www.treasury.gov/resource-center/terrorist-illicitfinance/Documents/FinCEN-Hawala-rpt.pdf.

Khan, M. (2006). Eyewitness to pain. Islamic Horizons, (January/February), 23.

Luanay, R. (1992). Beyond the stream: Islam and society in a West African town. Berkeley, CA: University of California Press.

Mandaville, P. (2013). Islam and exceptionalism in American political discourse. PS: Political Science and Politics, 46(2), 235-239.

Al-Marayati, S. (2004, October 21). Outside view: Picking on U.S. Muslims. United Press International. Retrieved from www.upi.com/Defense-News/2004/10/21/Outside-View-Pickingon-US-Muslims/11291098345900/.

McCutcheon, R. T. (1997). Manufacturing religion: The discourse on sui generis religion. New York, NY: Oxford University Press.

McKinnon, J., Chorney, J., \& Carnig, J. (2001, November 8). Feds target “dangerous” Hawalas: Local immigrants stress necessity of transfers. San Mateo County Times, front page.

Moyers, R. (2002). A shocking silence on Muslim charities. The Chronicle of Philanthropy, 15(1).

Obama, B. (2009, June 2). On a new beginning. Remarks at Cairo University, Cairo, Egypt. Retrieved from www.whitehouse.gov/the-press-office/remarks-president-cairo-university-6-0409 
Otto, R. (2010). The idea of the holy: An inquiry into the non-rational factor in the idea of the divine and its relation to the rational (Das Heilige) (J. W. Harvey, Trans.). Mansfield Centre, CT: Martino Publishing. (Original Work Published 1917)

Payton, R. L., \& Moody, M. P. (2008). Understanding philanthropy: Its meaning and mission. Bloomington, IN: Indiana University Press.

Reuters. (2004, June 2). U.S. Treasury names Islamic finance methods adviser.

Sabra, A. (2000). Poverty and charity in medieval Islam: Mamluk Egypt, 1250-1517 (Cambridge studies in Islamic civilization). Cambridge, UK: Cambridge University Press.

Saih, J. E. (2008, July 31). Interview by ACLU. Blocking faith, freezing charity: Chilling Muslim charitable giving in the "War on Terrorism Financing," p. 89.

Shaw, R. (1995). Feminist anthropology and the gendering of religious studies. In R.

McCutcheon (Ed.), The insider/outsider problem in the study of religion: A reader (pp. 104113). New York, NY: Continuum.

Siddiqui, S. (2013). Myth vs. reality: Muslim American philanthropy since 9/11. In T. Davis (Ed.), Religion in philanthropic organizations: Family, friend, foe? (pp. 203-214). Bloomington, IN: Indiana University Press.

Siddiqui, S. (2010). Giving in the way of God: Muslim philanthropy in the United States. In D. Smith (Ed.), Religious giving: For love of God (pp. 28-48). Bloomington, IN: Indiana University Press.

Singer, A. (2008). Charity in Islamic societies. Cambridge, UK: Cambridge University Press.

Skerry, P. (2006, August 14). The American exception: Homegrown terrorism in the U.S. Time.

Smith, J. Z. (1987). To take place: Toward theory in ritual. Chicago, IL:

The University of Chicago Press.

Smith, W. C. (1957). Islam in modern history. Princeton, NJ: Princeton University Press.

Turner, J. (2009). Blocking faith, freezing charity: Chilling Muslim charitable giving in the "War on Terrorism Financing. ” New York, NY: American Civil Liberties Union.

U.S. Department of Treasury. (2002, November). Anti-terrorist financing guidelines: Voluntary best practices for U.S.-based charities.

Wasserstrom, S. M. (1999). Religion after religion: Gershom Scholem, Mircea Eliade, and Henry Corbin at Eranos. Princeton, NJ: Princeton University Press.

Williams, G. (2004, October 28). Charities and foundations issue antiterrorism principles. The Chronicle of Philanthropy. 